\title{
Increase in lean mass may augment gains in bone mass and size in patients with osteogenesis imperfecta treated with bisphosphonates
}

Jaya Sujatha Gopal- Kothandapani, ${ }^{1,4}$ Shironisha Sritharan, ${ }^{2}$ Richard Jacques, ${ }^{3}$ Nick Bishop, ${ }^{1,4}$ Paul Dimitri ${ }^{5}$

1Department of Human Metabolism, 2Sheffield Medical School, 3 School of Health and Related Research, University of Sheffield, Sheffield, United Kingdom 4 Department of Paediatric Endocrinology, Sheffield Children's Hospital, Sheffield, United Kingdom

\section{INTRODUCTION}

- Osteogenesis Imperfecta (OI) is a disorder of bone fragility and repeated fractures, chiefly caused by mutations in the COL1A1 and COL1A2 genes that encode type I procollagen. ${ }^{1}$

- Treatment is aimed at increasing overall bone strength to prevent fractures and maintain mobility. ${ }^{1}$

- In patients with OI, bisphosphonate therapy results in age-adjusted change in total body and regional bone mass.

- In contrast changes in body size-adjusted bone mass in relation to changes in body composition following Pamidronate therapy remain relatively unexplored.

\section{AIMS}

- To determine the changes in total body and regional bone mass in relation to body composition in children with OI treated with Pamidronate.

\section{METHODS}

- Changes in total and regional bone mass in relation to body composition in children with OI receiving Pamidronate $(3 \mathrm{mg} / \mathrm{kg}$ per day over 3 days every 3 months) were analysed over 2 years.

- Total body less head (TBLH; subtotal) and lumbar spine (LS) bone mineral content (BMC-grams), bone area $\left(B A-\mathrm{cm}^{2}\right)$, areal bone mineral density ( $\left.\mathrm{aBMD}-\mathrm{g} / \mathrm{cm}^{2}\right)$, total body fat mass (grams) and lean mass (grams) were estimated by bone densitometry (DXA) in 26 children over 12 months and 17 children over 24 months.

- Weight, height and BMI SD scores were determined using 1990 UK Child Growth Foundation data. ${ }^{2}$

- All DXA measures were corrected for age and height.

- Volumetric bone density was corrected for age.

- Vertebral BMAD and volumetric BMD (BMDvol) were calculated by Carter and Kröger algorithms respectively. ${ }^{3}$

- The Carter method assumes that the vertebrae is a cylinder, while the Kröger method assumes it's a cube $\left(\mathrm{g} / \mathrm{cm}^{3}\right)$.

- The Carter model is made using the algorithm $B M A D=B M C / B A 1 \cdot 5$

- The Kröger model, BMDvol= BMC/volume= BMDareal $\times[4 / \pi \times$ width $)]$, where width $=$ mean width of vertebral body.

\section{RESULTS}

- Age of first treatment ranged from 0.57-5.6 years (mean $\pm S D=3.45 \pm 1.50$ ) - $81 \%(21 / 26)$ had type IOI; the remaining patients had type IV OI.

- There was no significant change in weight, height or BMI SD scores over 24 months.

- There was a significant increase in age and height-adjusted TBLH BMC, BA and LS BMD ( Fig 1) and age corrected BMAD (95\% Cl : $0.00,0.01, p=0.05$ ) over 12 months

Fig 1. Change in height, and age corrected subtotal BA, BMC and BMD at $12 \mathrm{~m}$

\begin{tabular}{|c|c|c|c|c|c|c|}
\hline & $\mathbf{N}$ & $\begin{array}{c}\text { Baseline } \\
\text { Mean (SD) }\end{array}$ & $\begin{array}{l}12 \text { Months } \\
\text { Mean (SD) }\end{array}$ & Change $^{1}$ & $95 \% \mathrm{Cl}$ & P-Value \\
\hline TBLH BA & 26 & $546 \cdot 3(177 \cdot 5)$ & $631 \cdot 7(192 \cdot 6)$ & $243 \cdot 0$ & $(126 \cdot 8,359 \cdot 1)$ & $<0.001$ \\
\hline TBLH BMC & 26 & $249.3(118 \cdot 8)$ & $305 \cdot 8(141 \cdot 7)$ & 139.7 & $(46 \cdot 9,232 \cdot 5)$ & 0.005 \\
\hline TBLH BMD & 26 & $0.439(0.099)$ & $0.463(0.099)$ & 0.053 & $(-0.093,0.199)$ & 0.459 \\
\hline LSBA & 26 & $13.65(3.79)$ & $15 \cdot 39(2 \cdot 82)$ & $2 \cdot 47$ & $(-4 \cdot 01,8.95)$ & 0.438 \\
\hline LS BMC & 26 & $8.44(3.83)$ & $7 \cdot 01(3 \cdot 78)$ & $2 \cdot 28$ & $(-0 \cdot 56,5 \cdot 12)$ & $0 \cdot 110$ \\
\hline LS BMD & 26 & $0.450(0.167)$ & $0.529(0.163)$ & $0 \cdot 118$ & $(0.020,0.216)$ & 0.021 \\
\hline
\end{tabular}

- From 12 to 24 months there was no change in height and ageadjusted bone measures.

- Total body fat mass and lean mass significantly increased after 12 months of therapy but only lean mass continued to increase from 12 to 24 months.

Fig 2,3. Change in age corrected fat mass, lean mass, truncal fat mass at $12 \mathrm{~m}$ and $24 \mathrm{~m}$.

\begin{tabular}{|lcccccc|} 
& $\mathbf{N}$ & $\begin{array}{c}\text { Baseline } \\
\text { Mean (SD) }\end{array}$ & $\begin{array}{c}\text { 12 Months } \\
\text { Mean (SD) }\end{array}$ & Change $^{1}$ & 95\% Cl & P-Value \\
\hline Fat Mass & 26 & $3749 \cdot 8(1091 \cdot 5)$ & $\begin{array}{c}4150 \cdot 7 \\
(1283 \cdot 1)\end{array}$ & $337 \cdot 4$ & $(17 \cdot 3$, & 0.040 \\
& & & $657 \cdot 5)$ & \\
\hline Lean Mass & 26 & $9153 \cdot 7(2505 \cdot 3)$ & $10382 \cdot 2$ & $968 \cdot 6$ & $(446 \cdot 5$, & 0.001 \\
& & & $(2778 \cdot 4)$ & & $1490 \cdot 8)$ & \\
\hline Truncal & 26 & $5638 \cdot 8(1495 \cdot 4)$ & $6427 \cdot 0$ & $745 \cdot 0$ & $(338 \cdot 8$, & 0.001 \\
Fat Mass & & $(1648 \cdot 7)$ & & $1151 \cdot 2)$ & \\
\hline 1Estimated change adjusted for height and age & & & \\
\hline
\end{tabular}

\begin{tabular}{|c|c|c|c|c|c|c|}
\hline & $\mathbf{N}$ & $\begin{array}{l}\text { Baseline } \\
\text { Mean (SD) }\end{array}$ & $\begin{array}{l}12 \text { Months } \\
\text { Mean (SD) }\end{array}$ & Change $^{1}$ & $95 \% \mathrm{Cl}$ & P-Value \\
\hline Fat Mass & 17 & $3858 \cdot 1(1137 \cdot 0)$ & $\begin{array}{c}4327 \cdot 3 \\
(1265 \cdot 0)\end{array}$ & $-166 \cdot 4$ & $\begin{array}{l}(-970 \cdot 1 \\
637 \cdot 3)\end{array}$ & 0.665 \\
\hline Lean Mass & 17 & $9736 \cdot 5(2245 \cdot 7)$ & $\begin{array}{l}10868 \cdot 8 \\
(2604 \cdot 5)\end{array}$ & $967 \cdot 2$ & $\begin{array}{l}(232 \cdot 0, \\
1702 \cdot 3)\end{array}$ & 0.013 \\
\hline $\begin{array}{l}\text { Truncal } \\
\text { Fat Mass }\end{array}$ & 17 & $6029 \cdot 5(1343 \cdot 7)$ & $\begin{array}{c}6725 \cdot 8 \\
(1581 \cdot 9)\end{array}$ & $545 \cdot 0$ & $\begin{array}{l}(-94 \cdot 7 \\
1184 \cdot 7)\end{array}$ & 0.089 \\
\hline
\end{tabular}

- In the first 12 months, change in lean mass was associated with an increase in TBLH BA and TBLH BMC.

\section{CONCLUSIONS}

- Pamidronate therapy had the greatest impact on size and age adjusted total body and lumbar bone density in the first 12 months

- The increase in lean mass compared to fat mass was more significant in the first year of therapy and was associated with an increase in total body bone mass and size.

- Lean mass continued to increase in the second year.

- We speculate that improved mobility may underlie these findings. 